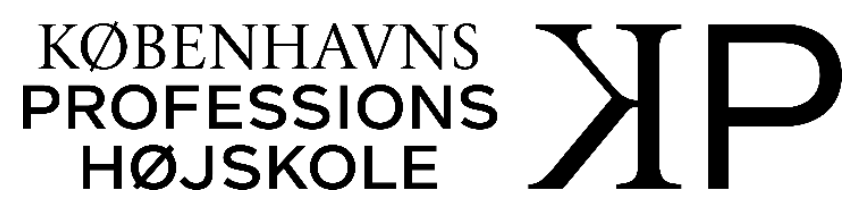

\title{
En guide til litteratursøgning og kildehenvisninger for bioanalytikerstuderende
}

Julie Smith, Christina Biber Hartz

Københavns professionshøjskole, 2019 


\section{Indhold}

Litteratursøgning og kildehenvisninger ................................................ 3

1. Litteratursøgning .................................................................... 3

1.1 Forskelligt kildemateriale ..................................................... 3

1.2 Hvorhenne kan jeg søge litteratur? .......................................... 4

1.3 Søgeteknikker og tips til søgning ..................................... 7

1.4 Fremskaffelse af litteratur .................................................. 11

1.5 Mere viden om litteratursøgning

2 Kildehenvisninger .................................................................. 13

2.1 Software til håndtering af referencer .................................. 13

2.2 Referencestandarder ................................................................ 14 


\section{Litteratursøgning og kildehenvisninger}

Denne vejledning kan anvendes af studerende $\mathrm{i}$ forbindelse med projektarbejde og udarbejdelse af rapporter - herunder også litteraturstudier, projektprotokoller og bachelorprojekter.

Vejledningen beskriver først selve litteratursøgningen (afsnit1), herefter beskrives, hvordan man laver kildehenvisninger i sin rapport (afsnit 2).

\section{Litteratursøgning}

Søgning af information og litteratur er en kontinuerlig og tidskrævende proces. Denne proces starter allerede under idéfasen af projektet, hvor problemstillingen og problemformuleringen skal indkredses. Litteraturen bliver således projektets videnskabelige fundament.

Eksisterende viden som anvendes i projektet skal være dokumenteret, og der udarbejdes derfor en litteraturliste (Se afsnit 2). Til dokumentation af faglig viden i projekter på Bioanalytikeruddannelsen er videnskabelige peer-reviewed artikler at foretrække, men anden faglitteratur kan også anvendes. For at indhente dokumenteret viden kræves det at kunne anvende søgeteknik, fremskaffe de fundne materialer, læse og forstå samt vurdere reliabiliteten af det læste. Men I vores videnssamfund drukner vi i information. Derfor er et godt råd, at øve sig i at danne overblik og læse selektivt om netop det, du har brug for, fremfor at læse materialet fra ende til anden - det gælder både videnskabelige artikler, fagbøger og anden faglitteratur (for at bruge din tid og koncentration effektivt).

\subsection{Forskelligt kildemateriale}

Det er en god start at få forståelse for et emne ved at læse i fagbøger, lærebøger og andet undervisningsmateriale. Viden kan også søges på Internettet og via portaler.

Den nyeste viden på et område får man typisk fra videnskabelige artikler skrevet af eksperter / forskere. Inden artiklerne udvælges til publikation i videnskabelige tidsskrifter vurderes de af andre eksperter / forskere på emnet (= peer-review). Hver artikel er forsynet med informationer som forfatter(e), titel, udgiver, udgivelsesår, sidetal og tidsskriftstitel. Derudover vil der ofte være et resumé (abstract), samt emneord (key words), der er tildelt den enkelte artikel.

Der findes primært to typer af videnskabelige artikler - originalartikler og oversigtsartikler:

Originalartikler indeholder original forskning, dvs de beskriver specifikke og originale videnskabelige arbejder, der ikke tidligere har været publiceret. De er typisk opbygget i IMRAD-format evt. med mindre variationer mellem de enkelte tidsskrifter.

Oversigtsartikler (eng. reviews) er videnskabelige litteraturstudier baseret på viden og tolkning af flere publicerede originalartikler. De er typisk skrevet af forskere, der er eksperter inden for et område. Reviews belyser således en problemstilling, ved at medinddrage flere originalartikler om emnet. Reviews er en god måde at få den nyeste viden med tolkning af originallitteraturen, og læses for at opnå overblik inden for et specifikt område. Modsat originalarbejde vil reviews typisk ikke opbygges i IMRAD format, fordi det ofte er 
uhensigtsmæssigt for belysning af emnet. Hvis formatet er IMRAD, så vil metodeafsnittet være litteratursøgningsprocessen, og resultater vil være de fundne litteraturkilder.

Vær kildekritisk! Er kilden troværdig og er kvaliteten i orden? Det er vigtigt at være kildekritisk, uanset hvor informationen stammer fra. Specielt med information fra internettet og gamle bøger. Indgår fejl / sproglige fejl? Bliver kilden opdateret / bliver den nyeste viden omtalt? Er det oplyst, hvem der har skrevet indholdet eller hvem, der står bag? Vær opmærksom på at firmaers hjemmesider er en del af deres markedsføring! Så en generel regel er at anvende anerkendte og navngivne steder som Sundhed.dk, Statens Serum Institut, U.S. National Institute of Health. Ofte findes mest fagligt detaljeret information på de engelske hjemmesider.

Men der findes også videnskabelige peer-reviewed artikler (både originale og reviewartikler), som er af ringe kvalitet, så her er det også vigtigt at være kildekritisk: Er metoderne velvalgte til at belyse formålet (laboratoriet/statistik)? Er resultaterne troværdige? Er diskussionen og konklusionen i tråd med resultaterne (både i selve artiklen og i abstract)? Måske overgeneralisering eller uoverensstemmelser? Med andre ord: husk altid at være kritisk og vurder validitet og reliabilitet.

\subsection{Hvorhenne kan jeg søge litteratur?}

Der findes søgemaskiner og bibliografiske databaser:

\section{Søgemaskiner}

Der findes forskellige søgemaskiner, men den mest kendte er nok Google. Søgemaskinerne har forskellig ranking (rækkefølge), f.eks. i forhold til relevans eller med det nyeste først. Så søg gerne på forskellige søgemaskiner, da ingen søgemaskine finder alt. Jo mere specialiseret viden desto vigtigere er det, at søge på forskellige søgemaskiner og søge avanceret.

\section{Google Scholar}

Google Scholar https://scholar.google.dk/ er en specialiseret søgemaskine, hvor der kan søges videnskabelig litteratur. Her findes videnskabelige artikler, bøger og akademiske afhandlinger. Scholar kan dog kun vise resultater fra de forlag, dokumentdatabaser og organisationer, hvor det er muligt for Scholar at få "adgang", såsom PubMed, men den finder ikke alt. Generelt har man med søgemaskiner ikke noget overblik over, hvad det reelt er, man søger i, altså hvilke kilder der er med i søgeresultaterne, men Scholar fungerer godt som supplement til de bibliografiske databaser.

Benyttes søgemaskinen Google Scholar til litteratursøgning, kan muligheden for fuldtekst adgang synliggøres ved at koble Google Scholar til bibliotekets adgange. Det kræver blot, at googleprofilen sættes op til at vise bibliotekets fuldtekst adgang, og er der ikke et link til hele teksten, kan artiklen bestilles. Læs mere om opsætningen af Google Scholar på https://phbibliotek.dk under Google Scholar i listen over databaser. Er man logget på netværket på Københavns Professionshøjskole (KP) behøver man ikke foretage sig noget, da Google Scholar per automatik er sat op med link til fuldtekst adgang. 


\section{De bibliografiske databaser}

Formålet med en bibliografisk database er, at identificere og lokalisere relevante dokumenter, primært videnskabelige artikler, men det kan f.eks. også være fagbøger eller disputatser (disputatser er akademiske doktorafhandlinger).

De bibliografiske databaser er forskellige med hensyn til indhold og dækning, hvor nogle spænder over stort set alle emneområder, mens andre er mere afgrænsede med et særligt fokus f.eks. farmakologi. Det skal dog siges, at ingen databaser dækker alt inden for et område, og det derfor ofte kan være en god ide at søge litteratur i flere databaser. Databasernes søgemuligheder kan være mere eller mindre avancerede. Der er udarbejdet vejledninger for hvordan man søger i databaserne, som findes under den specifikke database på https://phbibliotek.dk

I de internationale databaser er søgesproget engelsk og alle artikler er repræsenteret med et engelsk abstract, men artiklen kan stadig være på et andet originalsprog.

I det følgende præsenteres et udvalg af de databaser der er særlig relevante for bioanalytikerstuderende:

\section{PubMed}

PubMed er en international bibliografisk database fra US National Library of Medicine. Den dækker videnskabelige artikler inden for medicin, sygepleje, farmakologi, biokemi, biofysik, tandlægevidenskab og veterinærmedicin fra midten af 1950'erne og frem. Der er ca. 28 millioner referencer (nov. 2018) til artikler fra 4.800 biomedicinske tidsskrifter fra mange lande. De fleste artikler er forsynet med engelsk abstrakt.

Biblioteket anbefaler, at man tager adgang til PubMed via KPs biblioteksadgang, og dermed får man glæde af de tidsskrifter, hvor biblioteket har købt fuldtekst adgang til (se også Figur 5).

\section{Embase}

Biomedicinsk, farmakologisk bibliografi, dækker fra 1974 og frem. Embase's fordel er dens dækning af europæisk tidsskrifter og omfattende indeksering af lægemidler. Den er et vigtigt supplement til Pubmed, da den indeholder langt mere farmakologisk litteratur inden for de samfundsmedicinske områder som ikke er i PubMed. Basen har over 32 millioner referencer (nov. 2018).

\section{SveMed+}

SveMed+ indeholder ca. 100.000 artikler inden for biomedicin, patientinformation og kliniske aspekter inden for sundheds- og sygehusvæsnet fra skandinaviske tidsskrifter, rapporter og akademiske afhandlinger. Basen dækker fra 1978 og indekserer ca. 100 forskellige tidsskrifter, hvoraf flere er ikke indekseret i Pubmed. Basen er mere populærvidenskabelig end Pubmed, men dens force er dens skandinaviske dækning. Søgesproget er svensk eller engelsk. OBS! Der er kun i enkelte tilfælde link til fuld tekst. Prøv eventuelt at søge i andre databaser eller spørg på biblioteket.

\section{Cochrane Library}

Cochrane Library består af syv forskellige databaser, der kan bl.a. søges efter systematiske oversigtsartikler (reviews), metaanalyser, kontrollerede fors $\varnothing \mathrm{g}$, metodologiske studier, medicinske teknologivurderinger og økonomiske evalueringer (Det Nordiske Cochrane Center, 2006). Cochrane er et internationalt uafhængigt samarbejde hvor forskere bl.a. 
udarbejder systematiske kritiske oversigter (Cochrane Reviews) om virkninger af behandlinger og forebyggelse i sundhedsvæsenet. Hvert review er baseret på grundig søgning, kvalitetsvurdering og opsummering af resultater, de enkelte reviews opdateres løbende. Cochrane-samarbejdet startede i 1993. Cochrane reviews er medtaget i PubMed, men det kan alligevel være en god idé at søge særskilt i Cochrane Library for at sikre sig, at man ikke overser noget.

\section{Den Danske Forskningsdatabase}

Forskningsdatabasen (http://www.forskningsdatabasen.dk/) indeholder henvisninger fra danske universiteter, forskningsinstitutioner og andre offentlige institutioner, hvor formålet er at give en nem og enkel indgang til dansk forskning, Basen har over 1 million forskningsreferencer (nov. 2018) og indeholder forskellige typer forskningspublikationer f.eks. artikler, beskrivelser af forskningsprojekter, ph.d.-afhandlinger, mm. Der ligger også referencer til publikationer $\mathrm{mm}$., der kan være vanskeligt at finde andre steder. Databasen har afgrænsningsmuligheder, f.eks. kan man afgrænse til Ph.d.er eller Doktorafhandlinger. Forskningsdatabasen kan anbefales, hvis man har en særlig interesse i at undersøge, hvad der publiceres eller forskes i ved de 15 institutioner (nov. 2018), der leverer data. På forsiden af forskningsdatabasen, kan man se hvilke institutioner der er tale om. OBS! Der er kun i enkelte tilfælde link til fuld tekst. Prøv eventuelt at søge i andre databaser eller spørg på biblioteket.

\section{Københavns Professionshøjskoles Bibliotek}

På https://phbibliotek.dk kan man finde alle de materialer KPs bibliotek stiller til rådighed.

Det er også muligt at finde danske artikler fra tidsskrifter og aviser, samt gamle bachelorprojekter. Læs mere om hvordan I bruger biblioteket under "Sådan gør du" på phbibliotek.dk.

\section{Bibliotek.dk}

På https://bibliotek.dk/ findes en samlet indgang til al litteratur på de danske forsknings- og folkebiblioteker, der kan vælges at søge efter alle materialetyper eller begrænse til f.eks. bøger eller videnskabelige artikler. Det er muligt at se hvilke biblioteker, der har et givent materiale og bestille til hjemlån på eget folkebibliotek.

\section{Det Kongelige Bibliotek}

Basen REX http://rex.kb.dk giver adgang til at søge i alle materialer fra Det Kongelige Bibliotek og KUB, f.eks. bøger og tidsskrifter. Bemærk at adgangen til KB's databaser og elektroniske tidsskrifter sker fra Det Kongelige Bibliotek og dets filialer. Basen REX rummer bl.a. materialet fra

Det Natur- og Sundhedsvidenskabelige Fakultetsbibliotek

Nørre allé 49, 2200 København N.

På denne adresse kan man også møde op personligt og downloade det ønskede videnskabelige materiale. 


\subsection{Søgeteknikker og tips til søgning}

Sundhedsvidenskabelig information findes via Internettet, bibliografiske databaser, elektroniske tidsskrifter, bibliotekskataloger, portaler, søgemaskiner eller andre kendte hjemmesider.

Uanset om man benytter en søgemaskine eller en database skal man starte med at finde de ord, der beskriver problemstillingen. Start med at analysere emnet, lav f.eks. en brainstorm.

Hermed en liste over søgeteknikker og tips til søgning:

- Find ud af, hvad søgeordene hedder på engelsk. Findes der synonymer, forkortelser, andre begreber eller flere stavemåder (eksempelvis hemaglobine eller haemaglobine)?

- Når man skal lave større søgninger kan det være en fordel at dele sin søgning op i "blokke" - på den måde fås en systematisk tilgang til litteratursøgning og overblikket bevares over søgeordene. Inden du søger i databaserne kan du illustrere blokkene ved at bruge et aspektskema, hvor du udfylder dine aspekter vandret og synonymerne for hvert aspekt lodret. Du kan tilføje og fjerne ord løbende når du lærer mere om dit emne via litteratursøgningen. Se figur 1 som eksempel på hvordan du kan udfylde et aspektskema. Husk at søgesproget i de internationale databaser er engelsk - derfor er søgeordene i aspektskemaet på engelsk.

\section{Emne: Hvordan er PET og SPECT brugt i forhold til undersøgelse af hjerneskade?}

\begin{tabular}{|l|l|l|}
\hline Aspekt 1 & Aspekt 2 & Aspekt 3 \\
\hline PET & SPECT & Brain injury \\
\hline $\begin{array}{l}\text { Positron emission } \\
\text { tomography }\end{array}$ & $\begin{array}{l}\text { Single photon emission } \\
\text { computed tomography }\end{array}$ & Brain injuries \\
\hline PET/CT & SPECT/CT & Concussion \\
\hline & Optima NM/CT640 & \\
\hline
\end{tabular}

Figur 1. Aspekterne udgør de vigtigste ord i emnet. Under hvert aspekt er der fundet synonymer. Husk at tænke i over- og underbegreber, forkortelser og specifikke navne på f.eks. måle- og analyse maskiner.

- Søgeord kan skrives direkte i søgefeltet eller man kan benytte avanceret søgning. Se figur 2 som eksempel fra søgemaskinen Google Scholar. 


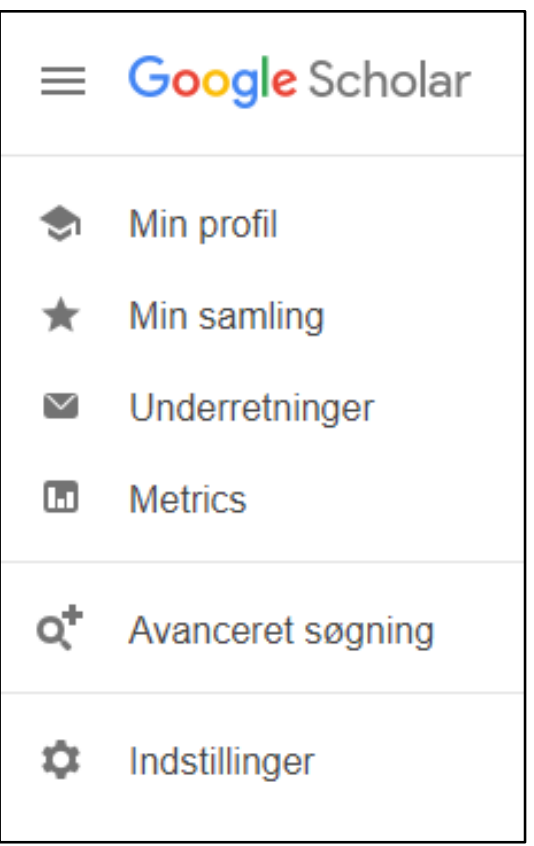

Figur 2. Avanceret søgning fra søgemaskinen Google Scholar. Klik på de 3 streger i venstre hjørne på Google Scholar for at få mulighed for avanceret søgning.

- Forsøg at vurdere videnskabelige artiklers relevans ud fra titlen og abstract, for at udvælge dem, man skal have fat på.

- Få løbende inspiration og information ud fra fundne artikler for nye søgeord /begreber.

- Husk at vurdere alderen på artiklen - Overvej hvor gammelt materiale, du accepterer indenfor netop det spørgsmål, du søger.

- Det er også en god idé at bruge litteraturlisterne fra artiklerne, da de ofte er gode kilder i sig selv til at finde litteratur.

- Frasesøgning ("...") gør det muligt at fastsætte en specifik rækkefølge af søgeord. Eksempel "blood group"(i stedet for blood group, hvor der da kan komme andre ord i mellem). Frasesøgning begrænser antallet af resultater, men kan være en god måde at præcisere søgningen på og kan også med fordel anvendes i søgemaskiner.

- Trunkering (*): Gør det muligt søge på flere varianter samtidig. På dansk har vi mange sammensatte ord. Hvis blod trunkeres: blod* - så vil søgningen inkludere blodanalyse, blodansamling, blodbank osv osv. Anvendes også på engelsk f.eks. vil en søgning på antisep* medtage antisepsis, antiseptic, antiseptics. Dog er trunkering ikke altid er en god løsning. Grundlæggende fungerer trunkering ens i alle databaser. Tegnet der anvendes til trunkering vil som regel være en *, men brug hjælpen i systemet til at finde ud af hvilket tegn I skal bruge og hvordan i den pågældende database. Søgemaskiner som Google trunkerer automatisk. 
- Boolske operatorer: Anvend boolske operatorer (se figur 3):
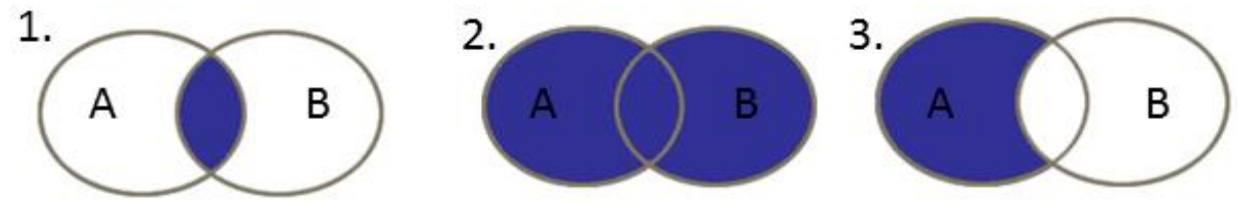

Figur 3: Anvend gerne boolske operatorer ("OR", "AND", "NOT") ved din søgning

1. A AND B betyder både ordet $A$ og ordet $B$ skal forekomme.

2. A OR B betyder enten A eller B skal forekomme.

3. A NOT $B$ betyder at ordet $B$ ikke må forekomme (pas på med denne søgeform)

I praksis sætter du OR mellem dine synonymer og AND mellem de forskellige aspekter i din problemstilling/emne. Se figur 4 for eksempel på hvordan de boolske operatorer skal forstås i forhold til aspektskemaet fra tidligere.

\section{Emne: Hvordan er PET og SPECT brugt i forhold til undersøgelse af hjerneskade?}

\begin{tabular}{|l|l|l|l|l|}
\hline Aspekt 1 & AND & Aspekt 2 & AND & Aspekt 3 \\
\hline PET & & SPECT & & Brain injury \\
\hline OR & & OR & & OR \\
\hline $\begin{array}{l}\text { Positron emission } \\
\text { tomography }\end{array}$ & $\begin{array}{l}\text { Single photon emission } \\
\text { computed tomography }\end{array}$ & & Brain injuries \\
\hline OR & & OR & & OR \\
\hline PET/CT & & SPECT/CT & & Concussion \\
\hline & & OR & & \\
\hline & & Optima NM/CT640 & & \\
\hline
\end{tabular}

Figur 4. Du sætter OR mellem dine synonymer, hvilket betyder databasen vil søge bredt og give resultater som indeholder et (eller flere) af dine søgeord i det enkelte aspekt. Til sidst sætter du AND mellem dine aspekter, hvilket betyder at databasen vil finde de resultater hvor et (eller flere ord) fra hvert aspekt indgår.

Biblioteket anbefaler at du i de internationale databaser søger et ord ad gangen og derefter kombinerer dine synonymer med OR i søgehistorikken. Dette gør du med alle dine aspekter. På den måde har du bl.a. overblik over hvor meget hvert enkelt ord fremkommer i databasen (hvor brugt er det? Skal du måske finde et bredere eller mere specifikt ord?), og du kan undgå stavefejl. Til sidst sætter du AND mellem dine aspekter og kan nu kigge på dit søgeresultat, hvor du har inkluderet alle aspekter. I figur 5 kan du se et eksempel på en søgehistorie i PubMed og kombinationen af først synonymer og derefter aspekter. 


\begin{tabular}{|c|c|c|c|c|}
\hline \multicolumn{3}{|l|}{ History } & \multicolumn{2}{|c|}{ Download history Clear history. } \\
\hline Search & Add to builder & Query & Items found & Time \\
\hline$\# 12$ & $\underline{\text { Add }}$ & $\begin{array}{l}\text { Search (((((PET) OR Positron emission tomography) OR PET/CT)) AND ((SPECT) OR Single photon } \\
\text { emission computed tomography)) AND ((concussion) OR brain injury) }\end{array}$ & 174 & 08:25:05 \\
\hline$\# 11$ & Add & Search (concussion) OR brain injury & 147035 & $08: 24: 59$ \\
\hline$\# 10$ & $\underline{\text { Add }}$ & Search concussion & 10576 & 08:24:53 \\
\hline$\# 9$ & $\underline{\text { Add }}$ & Search brain injury & $\underline{145427}$ & 08:24:47 \\
\hline$\# 8$ & $\underline{\text { Add }}$ & Search (SPECT) OR Single photon emission computed tomography & $\underline{41297}$ & 08:24:31 \\
\hline$\# 7$ & $\underline{\text { Add }}$ & Search Single photon emission computed tomography & $\underline{36118}$ & 08:24:12 \\
\hline \#6 & $\underline{\text { Add }}$ & Search SPECT & $\underline{41083}$ & 08:23:35 \\
\hline \#5 & $\underline{\text { Add }}$ & Search ((PET) OR Positron emission tomography) OR PET/CT & 118604 & 08:23:29 \\
\hline \#4 & $\underline{\text { Add }}$ & Search PET/CT & 18841 & 08:23:12 \\
\hline \#3 & $\underline{\text { Add }}$ & Search Positron emission tomography & $\underline{82326}$ & 08:23:03 \\
\hline$\# 2$ & Add & Search PET & $\underline{92888}$ & 08:22:34 \\
\hline
\end{tabular}

Figur 5. Synonymer for aspekt 1 er sat sammen med OR i søgning \#5, for aspekt 2 i søgning \#8 og aspekt 3 i søgning \#11. Aspekterne er sat sammen med AND i søgning \#12. I PubMed findes søgehistorikken under "Advanced".

Litteratursøgning en cirkulær proces. Det betyder at du ofte må tilbage og rette i dine søgeord undervejs. Når du søger et ord ad gangen kan du kombinere søgeordene på nye måder i din søgehistorie.

- Søgehistorik. I de fleste bibliografiske databaser kan I se, hvad I har søgt på i databasens søgehistorik. Søgehistorien kan anvendes til at kombinere søgninger. Lav eventuelt aspektskemaet, noter hvor I har søgt, på hvilke ord, antallet af hits og relevansen af de fundne resultater.

I mange databaser er det også muligt at oprette et login, således at søgninger kan gemmes direkte i databasen og senere hentes frem (se figur 6). I kan oprette e-mail alerts og få mails, når der kommer nye artikler, der matcher jeres gemte søgninger.

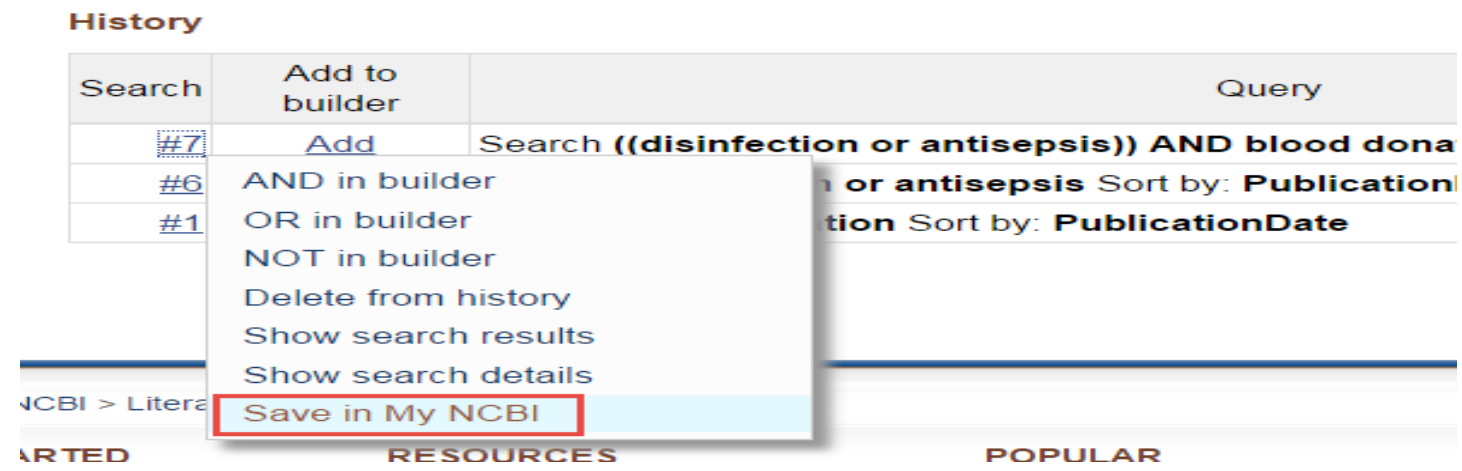

Figur 6 I PubMed skal man først oprette et log-in i øverste højre hjørne under "Sign in to NCBI". Så kan søgningen løbende gemmes med funktionen "Save in my NCBI".

- For specifikt at finde reviews, skriv da "review" sammen med jeres andre søgeord.

- Citationssøgning: En artikel modtager en citation, når en anden artikel henviser til denne i litteraturlisten. Ved nogle databaser og søgemaskiner er der også mulighed 
for at foretage søgning på disse citationer. Via funktionen "Citeret af", kan I se antallet og hvilke artikler der har citeret den pågældende artikel. Dette kan bruges til at finde artikler, der behandler samme problemstilling. Citationssøgning er kendt fra store internationale databaser som Web of Science (WoS) og Scopus og søgemaskinen Google Scholar. Du har adgang til alle disse via bibliotekets hjemmeside (under fanen databaser).

\subsection{Fremskaffelse af litteratur}

Et er at søge litteratur - Noget andet er at få adgang til hele teksten, og dermed også mulighed for at låne, downloade eller printe. Muligheder omtales her:

\section{Fagbøger}

Er det en bog eller et kapitel i en bog man ønsker at få fat i, er det bogens titel eller forfattere, der skal søges efter. Start i Bibliotekets database https://phbibliotek.dk, hvis bogen ikke haves eller er udlånt, og I ikke kan vente, så prøv Det Kongelige Bibliotek REX http://rex.kb.dk og/eller https://bibliotek.dk.

KPs bibliotek vil gerne have ideer til relevante bøger inden for dit fag, som kan købes til biblioteket.

\section{Videnskabelige artikler}

Nogle artikler stilles gratis til rådighed ("free full text" og "open access"), men oftest kræves abonnement på tidsskriftet for at få adgang til artiklerne. Derfor har KPs Bibliotek købt adgang til en lang række tidsskrifter, så studerende på KP hurtigt og enkelt kan få adgang til dem. En samlet liste over de elektroniske tidsskrifter biblioteket har adgang til, kan ses på https://phbibliotek.dk under databaser.

Når I skal have adgang til databaser er det vigtigt, at I går via biblioteket på KP https://phbibliotek.dk. På den måde får I mulighed for fjernadgang (adgang hjemmefra) via WAYF. For søgemaskinen Google Scholar se afsnit 1.2. Når I finder en artikel, kan I hurtig se om der er adgang til hele artiklen ved at klikke på ikonet for KP, som findes ud for hver artikel - se eksempel fra PubMed figur 7. 
Er der ikke elektronisk adgang har I mulighed for at bestille artiklen. Forvent en leveringstid på 2-7 dage. Har man ikke tid til at vente på leveringen, kan man gå forbi Det Natur- og Sundhedsvidenskabelige Fakultetsbibliotek (KUB-NORD), Nørre Allé 49. Medbring referencen, så I hurtigt kan undersøge om der er adgang til hele artiklen. Evt. undersøg tilgængeligheden inden via Det Kongelige Biblioteks (KB) database REX ( $\underline{\text { rex.kb.dk}}$ ).

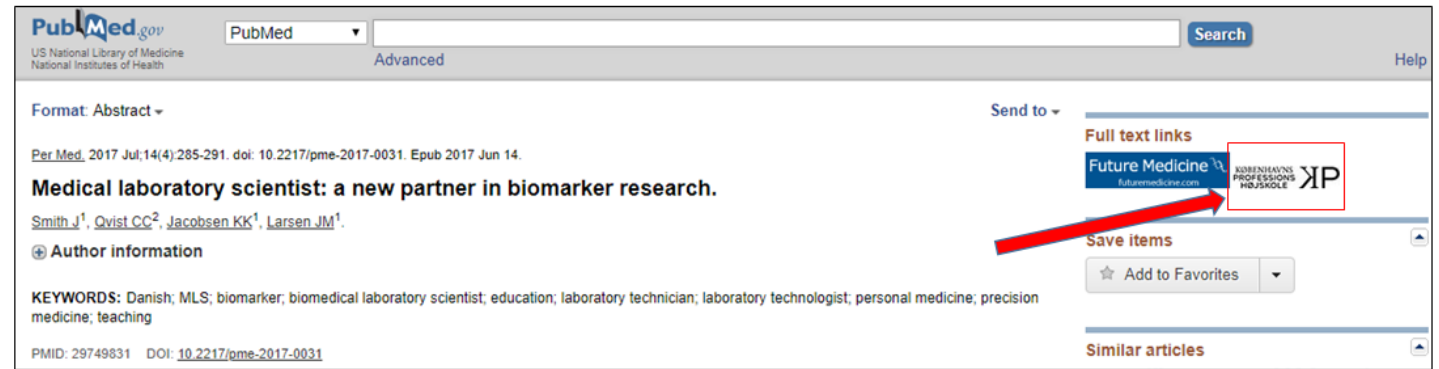

Figur 7. Eksempel fra databasen PubMed, der viser, hvor man kan tjekke om der er adgang til hele artiklen. Klik på ikonet for Københavns Professionshøjskole, hvis der ikke er adgang. Da kan artiklen bestilles via dette ikon / link.

\subsection{Mere viden om litteratursøgning}

Biblioteket har samlet e-læringsmateriale om bl.a. litteratursøgning i gruppen "Biblioteket" på Intrapol (https://Ims.intrapol.phmetropol.dk/cnnet/element/91553/frontpage). Første gang du besøger gruppen skal du tilmelde dig. Herefter finder du gruppen under Grupper/Undervisningsgrupper på Intrapol.

I gruppen kan du også finde information om kurser i f.eks. litteratursøgning og referencehåndteringsprogram. 


\section{Kildehenvisninger}

Referencer, der også kaldes litteraturhenvisninger eller kildehenvisninger, skal dokumentere og tydeliggøre at et udsagn bygger på andres videnskabelige arbejde. Derudover skal referencer også sikre, at det er muligt at identificere og genfinde de tekster, f.eks. bøger eller artikler, der er anvendt.

Når I skriver jeres rapport, skal der i teksten løbende henvises til referencer for at dokumentere udsagn, og alle de anvendte referencer skal fremgå af litteraturlisten. Man sætter referencer efter hvert faglige udsagn. Hvis samme afsnit kommer fra samme kilde(r) kan man sætte referencen(erne) til sidst i afsnittet.

Generelt foretrækkes det, at der refereres til originallitteratur-kilder. Det er vigtigt at finde originalartikler i diskussionen, så man kan sammenligne sine egne resultater med andres: Måske finder nogle forfattere samme resultat som jer, mens andre forfattere finder modsatrettede resultater.

Hvis det er mere generel baggrundsviden til f.eks. Introduktionsafsnittet, må man gerne henvise til en oversigtsartikel (eksempel "Kræft er den hyppigste dødsårsag i Vesten (Hansen et al)", da dette ofte ikke kan dækkes af en eller to originalartikler.

Der skal også laves kildehenvisning på citater. Citater er ordrette gengivelser af noget mundtligt eller skrifteligt. Korte citater sættes i citationstegn i den løbende tekst. Citater på over 2 linier markeres typografisk ved indrykning og linjeoverspring både før og efter citatet og enkelt linieafstand. Kildens ophav med årstal refereres efter citatet, mens litteraturlisten har den komplette kildeangivelse.

\subsection{Software til håndtering af referencer}

Referencehåndteringsprogrammer kan lette håndteringen af referencer, hvis man arbejder med mange kilder i rapporten. Referencerne kan importeres direkte til programmet fra databaserne, derved undgås stave/slåfejl, eller de kan indtastes manuelt. Herefter kan programmet, via et medfølgende plug-in til Word, anvendes til at udforme henvisninger og referenceliste efter den ønskede referencestandard f.eks. APA (alfabetisk rækkefølge) eller Vancouver (kronologisk rækkefølge).

Uanset hvilket referencehåndteringsprogram, der anvendes, er det vigtigt at tjekke om programmet har udført henvisningerne og referencerne korrekt, da der nogle gange sker programfejl.

Der findes mange forskellige referencehåndteringsprogrammer f.eks. Mendeley, Zotero og Refworks. Word har også en indbygget mulighed for kildehåndtering, den er dog ikke lige så avanceret som i de tre ovenstående.

KPs bibliotek har valgt at understøtte Mendeley, og holder kurser for studerende og gruppevejledninger, der kan bookes- se bibliotekets hjemmeside. På bibliotekets hjemmeside kan også findes vejledninger og hjælp til de nævnte referenceværktøjer. 


\subsection{Referencestandarder}

Ved udarbejdelsen af referencer er det vigtigt at medtage alle relevante oplysninger, der kan sikre genfinding, men også at være konsekvent i måden at angive dem på, både i teksten og i referencelisten. For at sikre denne kvalitet og ensartethed udarbejdes referencer efter standarder som f.eks. American Psychological Association (APA) eller Vancouver standarden.

Se i Boks 1-4 hvordan disse standarder anvendes i hovedteksten, og hvordan en litteraturliste opbygges med henholdsvis APA og Vancouver (bemærk forskelle i opbygning inklusiv tegnsætning som kommaer og punktum osv).

På nettet er der flere eksempler på, hvordan APA standarden og Vancouver standarden anvendes. Søg på eksempelvis APA citation style eller Vancouver citation style. Der findes også modificerede versioner af f.eks. Vancouver, et eksempel er BMJ Vancouver Style. Vancouver standarden (Boks 1 og 2) er den mest udbredte inden for sundhedsvidenskab, og f.eks. anvendes den i PubMed. Opbygningen af APA-style ses i Boks 3 og 4.

I må også lave jeres egen modificerede referencestandard med udgangspunkt i f.eks. APA eller Vancouver. Bare I gor det ens hele vejen gennem rapporten og sikre jer, at alle relevante oplysninger er med. 


\section{Boks 1}

Hvordan udarbejder jeg min litteraturliste med Vancouver-style? Ved Vancouver-style opstilles referencerne i litteraturlisten kronologisk efter den rækkefølge, som de optrådte i hovedteksten. Nedenfor ses eksempler:

Tidsskrifter (journals):

1. Goetze JP. Biosynthesis of cardiac natriuretic peptides. Results Probl Cell Differ. 2010;50:97120.

Det vil sige: Author(s) with Family name and Initials, Multiple authors separated by a comma. Title of article. Title of journal - abbreviated. Publication year; volume(issue):pages (Det er frivilligt om man vil inkludere måned/dato efter publikationsåret)

\section{Bøger:}

2. Butler SW. Secrets from the Black Bag. London: The Royal College of General Practitioners; 2005

Det vil sige: Author(s) with Family name and Initials, Multiple authors separated by a comma. Title of book. Edition of book if later than 1st ed. Place of Publication: Publisher Name; Year of Publication.

Online bog: [citationsdatoen er tidspunktet, du har fundet kilden]

3. Bartlett A. Breastwork: Rethinking breastfeeding [monograph online]. Sydney, NSW: University of New South Wales Press; 2005 [cited 2009 Nov10]. Available from: http://adat.crl.edu/ebooks/about/netlibrary

Regler for $\geq 1$ forfatter - gælder både bøger og tidsskrifter:

En forfatter

1. Snowdon J. Severe depression in old age. Medicine Today. 2002 Dec;3(12):40-47.

To til seks forfattere

19. McInnes D, Bollen J. Learning on the job: metaphors of choreography and the practice of sex in sex - on - premises venues. Venereology 2000; 13(1):27-36.

20. Skalsky K, Yahav D, Bishara J, Pitlik S, Leibovici L, Paul M. Treatment of human brucellosis: systematic review and meta-analysis of randomised controlled trials. BMJ. 2008 Mar 29;336(7646):701-4 .

Flere end 6 forfattere

Tidsskrift (journal):

21. Hanna JN, McBride WJ, Brookes DL, Shield J, Taylor CT, Smith IL, Craig SB, Smith GA. Hendra virus infection in a veterinarian. Med J Aust. 2006 Nov 20;185(10):562-64.

Ved bøger:

3. Hofmeyr GJ, Neilson JP, Alfirevic Z, Crowther CA, Gulmezoglu AM, Hodnett ED et al. A Cochrane pocketbook: Pregnancy and childbirth. Chichester, West Sussex, England: John Wiley \& Sons Ltd: 2008 


\section{Boks 2}

Hvordan refererer jeg i teksten med Vancouver Style?

Vancouver Style angiver referencer i hovedteksten ved fortløbende nummerering. Vancouver Style anvender arabiske tal i parenteser (1) eller som hævet skrift ${ }^{1}$. Dette gælder referencerne i både hovedtekst, tabeller og figurer. Tallet skal anvendes, selv om forfatteren(e) nævnes i sætningen / teksten, f.eks "Smith et al. have shown that... (10)". Hvis referencen "Smith et al" bruges senere i rapporten genanvendes det samme tildelte tal, som her (10) i dette eksempel.

\section{Eksempler på henvisninger i hovedtekst - Vancouver}

\section{En forfatter:}

Nielsen (1) compared methods $A$ and $B$, and found that......

Methods $A$ and $B$ have previously been compared in another study and.

Nielsen compared methods $A$ and $B$, and found that.....

To forfattere:

Mclnnes \& Bollen have developed a perspective which (19).

Ved tre eller flere forfattere bruges "et al":

By using meta-analysis, Skalsky et al found that....

\section{Ved flere referencer}

Når der citeres flere referencer er på et givet sted $\mathrm{i}$ teksten, skal du bruge en bindestreg til at beskrive fortløbende tal. Brug kommaer (uden mellemrum) til at adskille ikke fortløbende tal, f.eks $(2,3,4,5,7,10)$ forkortes $(2-5,7,10)$. Brug ikke en bindestreg, hvis der er 2 fortløbende tal f.eks skriv ikke (1-2), men skriv $(1,2)$.

Placeringen af citationstal inde i teksten bør nøje overvejes, f.eks en særlig henvisning kan være relevant for kun en del af sætningen. Eksempel:

"There have been efforts to replace mouse inoculation testing with invitro tests, such as enzyme linked immunosorbent assays $(57,60)$ or polymerase chain reaction $(20-22)$ but these remain experimental" 


\section{Boks 3}

Hvordan udarbejder jeg min litteraturliste med APA-style? Ved APA-style opstilles referencerne i litteraturlisten i alfabetisk rækkefølge efter forfatterens efternavn. Nedenfor ses eksempler:

Tidsskrifter (Journals):

Berndt, T. J. (2002). Friendship quality and social development. Current

Directions in Psychological Science, 11(4), 7-10.

Det vil sige: Author(s) Family name and initials and multiple authors separated by a comma. (year). Title of the Article. Name of the Journal, Volume Number (Issue Number), page numbers) Bøger:

McShane, S., \& Travaglione, T. (2007). Organisational behaviour on the Pacific Rim (2nd ed.). North Ryde, Australia: McGraw-Hill.

Det vil sige: Author(s) Family name and initials, Multiple authors separated by a comma. (Date of publication). Title of book (Edition of book if later than 1st ed). City, Publisher.

On-line bog:

Maclean, H. (1932). Nursing in New Zealand:History and reminiscences. Retrieved from http://www.nzetc.org/tm/scholarly/tei-MacNurs.html

\section{Regler for $\geq 1$ forfatter-gælder både bøger og tidsskrifter:}

En forfatter:

Berndt, T. J. (2002). Friendship quality and social development. Current Directions in Psychological Science, 11(4), 7-10.

To forfattere:

Wegener, D. T., \& Petty, R. E. (1994). Mood management across affective states: The hedonic contingency hypothesis. Journal of Personality and Social Psychology, 66(2), 1034-1048.

Tre til syv forfattere:

Kernis, M. H., Cornell, D. P., Sun, C. R., Berry, A., Harlow, T., \& Bach, J. S.

(1993). There's more to self-esteem than whether it is high or low: The importance of stability of self-esteem. Journal of Personality and Social Psychology, 65, 1190-1204.

Flere end syv forfattere:

Miller, F. H., Choi, M. J., Angeli, L. L., Harland, A. A., Stamos, J. A., Thomas,

S. T., , . Rubin, L. H. (2009). Web site usability for the blind and low-vision user. Technical Communication, 57, 323-335. 


\section{Boks 4}

Hvordan refererer jeg i teksten med APA Style?

En fordel ved APA er, at den anbringer forfatter og udgivelsesåret fremtrædende i hovedteksten. Det kan gøre det lettere for læser at danne sig overblik over referencerne. Eksempler på APAstyle henvisninger i hovedtekst:

Methods A and B have previously been compared in another study and...... (Nielsen, 2015).

Nielsen (2015) compared methods A and B, and found that..... .

In 2015, Nielsen compared methods A and B, and found that.. 